Article

\title{
QUARTERMASTERS OF STADIUMS AND CEMETERIES: NORMATIVE INSURRECTIONISM AND THE UNDER-THEORIZATION OF REVOLUTIONARY STRATEGY
}

\author{
JOSHUA MOUFAWAD-PAUL \\ York University
}

\begin{abstract}
Biographical Note
Joshua Moufawad-Paul lives in Toronto and works as adjunct faculty at York University where he received his $\mathrm{PhD}$ in philosophy. His first book, The Communist Necessity, was published in 2014.
\end{abstract}

\begin{abstract}
In this article, I examine the problematic of revolutionary strategy and how it is under-theorized at the centres of global capitalism, often confused with the theory of organization. Arguing that the theory of insurrection is uncritically accepted as normative, I discuss the necessity of returning to a critical engagement with the theory of strategy in the context of a modern capitalist military. By examining Karl Liebknecht's discussion of militarism, the a priori acceptance of the theory of insurrection by contemporary theorists in both the communist and anarchist traditions (i.e. Jodi Dean and the Invisible Committee), and the counter-tradition of protracted people's war, I demonstrate that the theory of insurrection is philosophically deficient, unable to account for the problems produced by capitalist militarism and pacification.
\end{abstract}

\section{Keywords}

Strategy, militarism, pacification, insurrection, theory

In Categories of Revolutionary Military Policy T. Derbent, a Belgian theorist of revolutionary strategy, writes:

Every social revolutionary project must think ahead to the question of armed confrontation with the forces of power and reaction. To put off making such a study because 'the time is not right yet' for armed confrontation, amounts to making choices... which risk, at that point when 'the time will be right' for armed confrontation, leaving the revolutionary forces powerless, vulnerable, with characteristics that will be totally inadequate. Choices which risk leaving them open to defeat. [...] Organizations that claim to be revolutionary but 
which refuse to develop a military policy before the question of confrontation becomes a practical reality, disqualify themselves as revolutionary forces. They are already acting as gravediggers of revolution, the quartermasters of stadiums and cemeteries. (Derbent 2013, 1-2) ${ }^{1}$

The significance of this statement is in its implied judgment about normative anti-capitalist practices at the centres of global capitalism. That is, despite occasional claims to the contrary, "in the advanced capitalist countries the question of... the strategic line of the revolution has become the most underdeveloped area... [the] least creative zone, the least productive." (Action Socialiste 2000) If the question of strategy is under-theorized in "advanced capitalist countries," as I shall argue in this paper, then it might be the case that we have indeed disqualified ourselves "as revolutionary forces."

The main contention of this essay is that revolutionary strategy is under-theorized at the centres of global capitalism due to an either uncritical or unconscious adoption of the strategy of insurrection inherited from the October Revolution in Russia. Furthermore, I argue that the question of strategy, though frequently named, is often confused with the related questions of organizational form and tactics rather than the problematic of strategy itself. Although these related questions are indeed important, they tend to accept the strategy of insurrection as a priori; in many cases, these examinations of strategy do not appear to be aware that their assessments of organization and tactics presuppose the theory of insurrection. My overall position is that we need to critically engage with the problematic of revolutionary strategy rather than delaying this problem until a future-perfect scenario when "the time will be right."

The first section of my paper will examine the necessity for a theory of revolutionary strategy: in the context of a modern militarized state designed to pacify unruly populations, we cannot simply assume that the problem of armed confrontation between the state and anti-capitalists will spontaneously solve itself; nor should we be unreflective about the strategic theory we have inherited from a revolution where the state forces did not resemble the modern capitalist military. The second section will examine the theory of insurrection that we have uncritically inherited from the Russian Revolution--a protracted legal struggle that will lead to a large-scale uprising where, perhaps after a civil war, the state is overthrown--and argue that it has become the normative theory of strategy, though often unconsciously accepted, by the majority of left-wing academics and activists at the centres of capitalism. The third section will examine in detail two paradigm-examples of this normative acceptance of the insurrectionary strategy. The final section will discuss the

\footnotetext{
${ }^{1}$ Derbent's work on revolutionary warfare and military theory is better known in French-speaking contexts due to the fact that only the above cited treatise is translated into English. His two significant books are Clausewitz et la Guerre Populaire (Brussels: Editions Aden, 2004) and Giap et Clausewitz (Brussels: Editions Aden, 2006), which are currently only available in French.
} 
possibility of an alternative to the theory of insurrection and what it might mean to return to critically theorizing strategy in the context of modern militarization and pacification.

1

In Militarism, Karl Liebknecht argued that a general theory of strategy was "almost lacking in the case of proletarian revolution." (Liebknecht 1917, 15) Having examined the emergence of a capitalist military, and the strength of the military and police in the pacification of unruly populations, Liebknecht claimed:

the superiority of the army to the unarmed people, the proletariat, is far greater today than it was ever before on account of the highly developed military arts and strategy, the enormous size of the armies, the unfavorable local distribution of the various classes and the relative economic strength of proletariat and bourgeoisie which shows the proletariat in a particularly disadvantageous position, wherefore alone a future proletarian revolution will be far more difficult than any revolution that has taken place hitherto. (Ibid., 177-178)

More than fifty years prior to Liebknecht's Militarism, Engels had written: "[t]he emancipation of the proletariat, too, will have its particular military expression, it will give rise to a specific, new method of warfare." (Engels 1978, 553) Whereas Engels concluded this passage by claiming "[i]t is even possible to determine the kind of material basis this new warfare will have," (Ibid.) Liebknecht claims that such a determination does not yet exist a particular problem due to the "superiority" of bourgeois military might.

We should understand this "superiority", or "the highly developed military arts and strategy" of the capitalist state, in the sense indicated by the concept of pacification discussed in a past issue of The Journal for the Society of Socialist Studies. That is, the might of capitalist militarism is not dependent simply on its 'purely' military aspect but also in "psychological action, propaganda, political and operational intelligence, police measures, personal contacts with the population, and a host of social and economic programs" (Neocleous, et al. 2013,1 ). Hence, there is a need for a general (or, to use a more theoretical term, a universally applicable) theory of revolutionary strategy that can account for this reality. In any case, due to the military strength (in the broad sense, implied both by Liebknecht and the notion of "pacification") of modern capitalism, a theory of strategy capable of engaging with this reality becomes necessary.

Although Militarism is not a well-known text, perhaps because Liebknecht's theoretical output was overshadowed by the work of Rosa Luxemburg, it is significant in its prescience. Arguing that capitalism necessarily needs an army and a police in order to 
protect its existence, Liebknecht understood that such a need was balanced by the fact that capitalism was forced to draw the members of its military from the ranks of the people it sought to police. Hence capitalism faced several significant problems in the maintenance of such an army: i) a standing army consisting of required military service would result in an armed and trained working-class population; ii) drafts for imperialist wars would disaffect the population capitalism sought to rule; iii) constant and outright coercion of populations would be unproductive for the day-to-day business of capital. Capitalism thus required an ideology of militarism that would allow the working-class and possible members of the army to consent to class rule, an ideology that would be expressed at every societal level: "a system of saturating the whole private and public life of our people with the military spirit for which purpose the church, the schools, and a certain venal art, as well as the press, a despicable literary crowd and the social prestige, with which our 'splendid war army' is ever being surrounded as by a halo, cooperate in a tenacious and cunning fashion." (Liebknecht 1917, 90-91)

Aside from this important insight about the nature of capitalist militarism--an insight that prefigures Antonio Gramsci's concept of hegemony and Michel Foucault's concept of governance--the significance of Militarism, for the purpose of this essay, is the concern Liebknecht expressed above: the possibilities of revolutionary strategy in the face of an immanent and powerful militarization. Motivated by the aim of overthrowing the society upon which this militarism depended, Liebknecht wondered at the lack of a strategic theory that was capable of taking the organized might of capitalist coercion, as well as its ideological hegemony, into account. Since this book was written around a decade before the October Revolution, though, it is worth wondering whether the theory derived from this experience, the general theory of insurrection (also called "the October Road"), satisfied the theoretical lacuna indicated by Liebknecht. After all, the lack of theorizing described by Liebknecht may have been satisfied by the emergence of a theory of how to make revolution, supposedly proven by the revolution in Russia.

As I will discuss in the following pages, the theory of insurrection fails to satisfy the requirements implied by Liebknecht's analysis; a proper strategy of making revolution is still, at least at the centres of global capitalism, underdeveloped. Moreover, it is also significant that Liebknecht, writing eleven years before the Bolshevik insurrection and civil war, saw that the solution to his problem might be found in " $\mathrm{t}]$ he tactics of the urban guerrilla method, splendidly developed in Moscow [in 1905]," and that such a development would be "epochal." (Ibid., 15) Here we find the possibility of a process, obscured by the theory of insurrection, that begins in 1905 and concludes in 1917: it may be possible, as I will discuss in the final section of this paper, to imagine a general theory of revolutionary strategy gleaned from this process rather than from a single moment that was mistaken for the general theory.

If anything, the military forces and technologies of contemporary capitalism are even more extensive than when Liebknecht wrote Militarism. To imagine that we can solve this 
problem of strategy in the same way it was solved in Russia in 1917, where the enemy's military strength was already in shambles and its army possessed semi-feudal characteristics, is the result of lazy thinking. Unfortunately, as I shall hopefully make clear, this lazy thinking has become normative at the centres of global capitalism.

2

The theory of insurrection, "[f]irst implemented in October 1917 and meticulously theorized thereafter,"(Derbent 2013, 18) can be summarized according to the following points: i) revolutionaries embark on a period of legal agitation amongst the people that will produce disaffection with the system and a heightened anti-capitalist consciousness; ii) this disaffection leads to rebellions wherein further agitation can produce a stronger revolutionary consciousness; iii) these rebellions produce a large-scale insurrection in which the people can be organized, by whatever means, into a force capable of overthrowing capitalism, possibly through a civil war.

The reason I have chosen to begin this section with a general summary of the theory of insurrection, rather than the particular Marxist-Leninist variant that is arguably its point of origin, is because I contend that the theory's normative status is such that one does not have to be a Leninist to accept its veracity. Indeed, the Invisible Committee's book The Coming Insurrection, once a popular radical text for the anti-Leninist left, is premised on the theory of insurrection. Moreover, although there are those who reject revolutionary strategy altogether, in this paper I am interested only in the "anti-capitalist left" (whether they define themselves as anarchists, communists, socialists, etc.) that begins by assuming that capitalism cannot be reformed, and that the entire system ought to be replaced with something more humane.

Having reached a certain level of normativity at the centres of global capitalism amongst the aforementioned anti-capitalists, the insurrectionary strategy is rarely examined in a critical sense, except when the problem of organization is considered. Often an insurrectionary destiny is treated as a priori, reified behind discussions and debates of the proper organizational form. Thus, when Socialist Register produced an issue devoted to "the question of strategy," not a single article focused on the theory of strategy itself; rather, it examined particular tactics (i.e. the "Occupy" movement, the role of the democratic process, unions, reformist movements) and by what organizational means revolutionary strategy could be implemented. (Panitch, et al. 2013) Even recent academic treatments of revolutionary strategy that do not confuse strategy with organization begin by accepting the feasibility of insurrection, focusing mainly on tactical concerns. Daniel Egan's "Rethinking War of Maneuver / War of Position", for example, argues that Gramsci's understanding of Clausewitz was inferior to Trotsky's, but this inferiority is deduced by the a priori assumption that the theory of insurrection is the only way to make revolution in advanced capitalist 
contexts since its paradigm model for revolutionary warfare is the October Revolution. (Egan 2014)

Although discussions of the place of particular tactics in a revolutionary movement, and the viability or antiquated nature of a Leninist-style party, are indeed important, the problem is that these often rest on a fidelity to insurrectionary strategy. For example, while Stephen D'arcy's article "Strategy, Meta-strategy and Anti-capitalist Activism" (D'arcy 2009) is notable in that it does grasp that strategy is not a synonym with organizational form, his essay that is ostensibly about strategy is still primarily about the viability of the Leninist form of organization. ${ }^{2}$

Of course, if we attach this theory to its organizational point of origin, the Leninist "party of the avant garde", then we can understand a particular variant of the theory that is purely Leninist. The orthodox Leninist party is an organizational form that leads precisely to a revolutionary strategy lifted from the October Revolution. ${ }^{3}$ There is a logical destiny of the purely Leninist party; it follows directly from the assumption that the revolutionary party is a "general staff" of elite managers who are the perfect stand-in of the proletariat. The perfect Leninist party makes revolution in a rather straight-forward manner: circulate amongst the masses and involve oneself in a protracted legal struggle designed to push traditional workers organizations (i.e. trade unions) towards the moment of general strike; use every possible economic struggle, every strike, in a way that teaches those with "trade-union consciousness" to move towards "revolutionary consciousness"; eventually, if the protracted legal struggle is successful, when the moment of the general strike arrives the party cadre can affect a massive break from trade-union consciousness, forcing a civil war; the army and police will be split, the party that was most disciplined and aware will grow exponentially so as to lead the masses in insurrection. (Neuberg 1970) Here, the fundamental theory of organization, the party formation, receives its ultimate meaning in the crucible of

\footnotetext{
${ }^{2}$ That is, D'arcy makes a distinction between strategies of "overthrow" and "attrition"--thus claiming, pace Derbent and somewhat oddly--that a revolutionary strategy is not necessarily about the overthrow of the capitalist state and that we should instead adopt what, to my mind, is a non-strategy of "attrition" dedicated to harrying capitalism and rebuilding the left. (D'arcy 2009, 76-77) Strategies of "overthrow" (the very definition of revolutionary strategy) are treated as synonymous with the concept of the Leninist party; D'arcy's discussion of "attrition" is primarily a critique of Leninism, and thus the need to build new organizations, that he brands strategic. Hence, by defining his theory of strategy as "a guide for conducting political action today with a view to laying the foundation for a revolutionary transformation in the future," (Ibid., 77), D'arcy is ultimately discussing organization rather than strategy.

${ }^{3}$ Although we can argue that the theory of insurrection could have been theorized earlier by Auguste Blanqui, this version was less clear and closer to (though not the same as) the strategy of a coup. This is not to say that the theorization that emerged after 1917 was not influenced by the event of the Paris Commune--or that we cannot understand the Paris Commune by retroactively applying the post-1917 theory of insurrection--only that the theory Blanqui calls "insurrection" is somewhat alienated from the way we understand it now. Hence, we should treat the theory of insurrection gleaned from the October Revolution as being the first clear expression of insurrectionary strategy.
} 
insurrection.

As noted above, the general theory of insurrection does not have to be Leninist. Those who adopt some form of "movementist" ideology (that is, a social movementism, whether it be anarchist or autonomist, that relies on the spontaneity of the people and rejects, to whatever degree, the need for a revolutionary party) also treat this strategy as a priori, but without "providing a schema for what an insurrection should be." (The Invisible Committee $2009,19)$ Here the argument is that we do not need a single organization to act as a "general staff" of the people, or that we even need to think about organizing only the working-class since there may be other sites of oppression that require our attention. Rather, the insurrection is treated as an event that, though encouraged by difficult consciousness-raising, and working with a variety of organizations and individuals, will emerge spontaneously. In their self-organization the people will launch an insurrection that will topple capitalism. Although I may be homogenizing various tendencies in the category of movementism, ${ }^{4}$ I am doing so simply to describe the normative prevalence of the theory of insurrection. This normativity is expressed whenever there is an uprising: in the anti-globalization movement, in Occupy, in some of the assessments made about the Arab Spring, we can find a reified theory of insurrection.

In contradistinction to the Leninist articulation, then, the movementist variant of insurrectionary strategy argues that "[t]he militarization of civil war is the defeat of insurrection. The Reds had their victory in 1921, but the Revolution was already lost." (Ibid., 129) This particular non-Leninist normalization of the strategy celebrates the moment of historical insurrection itself (that is, 1917) as the site of revolution rather than the military activity, produced and galvanized by this insurrection, that led to the defeat of the White Army. However we may choose to interpret this difference, though interesting, is tangential to the fact that an unquestioned fidelity to insurrection is prevalent amongst those sections of the left that reject reformism.

A theory's prevalence, however, does not make it correct. Rather, it is my contention that this acceptance of the theory of insurrection is usually treated as an article of faith. There is no reason to accept this theory as universally applicable; aside from the October Revolution, it has never been successful. For nearly a century, those anti-capitalist organizations pursuing this strategy--either directly or vaguely--have nothing to show for their attempts, especially since "[t]his strategy met with major failures in Germany (1923), China (1927), Austria (1934), Brazil (1935), and elsewhere."(Derbent 2013, 19) In fact, the only post-1917 instances where insurrections have been somewhat successful are in situations where many popular forces have been organized by reactionaries (i.e. as in the case of the 2014 Ukraine rebellions), which is significant: these reactionary-led rebellions tend to find allies amongst the ruling classes, or receive the military backing of imperialist powers,

\footnotetext{
${ }^{4}$ In my book The Communist Necessity (Montreal: Kersplebedeb, 2014) I provide a more sustained critique of movementism.
} 
and are thus closer to coups than insurrections regardless of how they may appear.

"Amongst true-believers in 'insurrection theology," writes Derbent, "[the insurrection] is somewhat like a horizon: the more they move towards it, the further it moves away." (Derbent 2013,25) Hence, it may be significant that some of the popular texts that are supposedly about revolutionary strategy do indeed conceptualize the revolutionary moment as a distant horizon in a quasi-eschatological sense.

Take, for example, Jodi Dean's The Communist Horizon where the theory of insurrection is indeed reified so that the insurrectionary event lurks at distant and under-theorized point. Although Dean does not really address the strategic concerns of making revolution, she does not have to because insurrection is an assumption of her "horizon". Revolutionary strategy becomes conflated with the problem of organization and the resolution of the latter is presumed to predestine the former.

In examining the failed Occupy uprising in the US, Dean is most concerned with figuring out how this movement demonstrates a possibility of communism that can become actual once the problem of organization is solved. (Dean 2012, 207-250) She exhorts us to return, though in a critical manner, to Lenin and argues that the Occupy movement already possesses (or, rather, possessed) the kernel of a quasi-Leninist party. (Ibid., 233) In this context, Dean understands the strategic problem as how best to actualize this nascent Leninism. (Ibid., 240-241) Occupy, however, was a mass movement that emerged to confront the state directly, albeit incoherently; the meaning of its event was insurrectionist since it sought, in the manner of a general strike, to force a direct confrontation between the 99\% and the $1 \%$, often hoping to split the ranks of the police that defended the existence of the latter. "You are part of the 99\%," was a common slogan, during the days of the failed Occupy movement, levelled at the armed women and men who assembled to defend the state in the hope that these guardians of capitalism would align their interests with the occupiers.

The fact that Dean believes that such movements can produce a neo-Leninist organization capable of making communism an actuality, and is disinterested in thinking through the strategic problems inherent in such a practice, demonstrates an uncritical acceptance of the theory of insurrection. Her problem with the movement was not the strategic aspect of its practice but only the absence of a superior principle of organization. Indeed, she is quite clear that we do not need to reconceptualize a theory of strategy, or that such a theory is even necessary, since revolutions "are results, conditions, and effects of politics wherein states are overthrown, dismantled, distributed, reconfigured, redirected." (Ibid., 240) Despite implying that a strategy of making revolution will emerge spontaneously when it is necessary, and thus conflating organization with strategy, Dean is also endorsing a vague insurrectionism due to her preferred example: "Occupy arranges the 
physical presence of large groups of people outside, in visible, urban spaces, in political actions authorized by neither capital nor the state but by the people's collective will." (Ibid., 233) What she is describing is an insurrectionary event, the moment when the people openly manifest so as to directly challenge the state.

Here, it is worth asking whether or not the 'Leninization' of Occupy would have brought us closer to the actualization of communism, as Dean seems to imply. That is, if the occupiers all happened to be Leninists when they emerged to "occupy Wallstreet" (and other places), would they have been able to defeat capitalism? While they might have been better organized theoretically, unified as a party with some manner of class consciousness, the state would still be better prepared to win the confrontation. Simply possessing a different level of theoretical unity, and a proper understanding of class conflict, would not have made any of the occupiers proficient military strategists or tacticians; they would still lack the concrete means to defeat capitalism's military might.

Indeed, the very fact that Dean treats the Occupy movement as a space that could become revolutionary if it was organized according to a specific understanding of Leninism demonstrates an unquestioned fidelity to the theory of insurrection. For Dean, Occupy was potentially revolutionary because it emerged to directly confront capitalism in the manner of an insurrection, and it failed because it lacked Leninist unity. Although it might be the case that Dean is correct about the problem of organization, the fact that she simply ignores the questions of strategy that the Occupy movement could not answer demonstrates a lacuna in thought. We know that Occupy failed because the state was successful in keeping it contained. To assume that this movement could have breached its containment by possessing a higher level of unity is to assume that the theory of insurrection is correct: that a coherent revolutionary movement that arms itself in the moment of insurrection in order to end capitalism, despite its lack of training, will succeed because of its organizational coherence. Such an assumption flies in the face of history.

A similar faith in insurrection, as aforementioned, can be found in the Invisible Committee's The Coming Insurrection, a paradigm-example of an anti-capitalism that rejects Leninism. Unlike Dean, whose endorsement of the theory of insurrection is implicit, the Invisible Committee actually ends its seminal text with an explicit summary of this theory. Although there is nothing unusual in this summary, it is notable in the problems resulting from its devotion to insurrection. For example, the Invisible Committee argues for the necessity of taking up arms at the insurrectionary moment, but only insofar as it is tactically important: "the question of pacifism is serious only for those who have the ability to open fire. In this case pacifism becomes a sign of power, because it is only in an extreme position of strength [i.e. in the spectre of being an armed insurrectionary force] that we are freed from the need to fire." (The Invisible Committee 2009, 129)

Furthermore, although the Invisible Committee recognizes that military confrontation between armed insurrectionists and the militarized state "would require that the state be committed to a bloodbath," it dismisses this situation as "no more than a threat, 
a bit like using nuclear weapons for the last fifty years." (Ibid., 130) From this dogmatic assumption--dogmatic because it assumes a priori, without any evidence beyond a moralistic assumption, that the state is not committed to putting down an insurrection with or without a "bloodbath"--the authors of The Coming Insurrection assume that the doctrine of splitting the police and military's ranks is correct: "[a] massive crowd would be needed to challenge the army, invading its ranks and fraternizing with the soldiers. [...] An insurrection triumphs as a political force. It is not impossible to defeat an army politically." (Ibid.) Just why it is assumed that the defeat of the capitalist military is "not impossible" is never explained; it is a presupposition inherited from the normative status of insurrectionary strategy. Liebknecht's analysis of militarism, however, should lead us to another conclusion: we should demand an analysis, on the part of the Invisible Committee, of those state forces that can supposedly be defeated politically and how such a defeat is even possible. Unfortunately, the authors provide no reason for this claim aside from their statement of fact.

What is interesting about the Invisible Committee's reliance on the theory of insurrection, though, is that, right at the moment they presuppose the doctrine of insurrection, they also claim that "[f]rom a strategic point of view, indirect, asymmetrical action seems the most effective kind, the one best suited to our time: you don't attack an occupying army frontally." (Ibid., 129) Here we find the germ of a strategic theory that is counter to the theory of insurrection in that it advocates a different revolutionary policy, but one that the Invisible Committee quickly abandons because it threatens their devotion to what is normative: "the prospect of Iraq-style guerrilla warfare, dragging on with no possibility of taking offensive, is more to be feared than desired." (Ibid.) The reason for this fear is not simply due to the protracted nature of such a strategy but because, due to the Invisible Committee's overall theoretical commitment, it is a form of militarization and thus what they have already rejected in their de-Leninization of insurrection. Hence, despite recognizing the significance of an alternative to the insurrectionary strategy, the normative theoretical constraints constrict to smother this insight--an insight that unconsciously echoes Liebknecht's claim about the significance of the guerrilla tactics of 1905.

Although both Dean and the Invisible Committee differ on the theory of organization, they are united in their "insurrection theology." Whereas the former makes the common mistake of substituting the problem of strategy for the problem of organization, the latter refuses to take the problem seriously in its very description of the theory of insurrection.

The military machinery of the capitalist state, described before its full emergence by Liebknecht, is the primary obstacle for a general strategy of insurrection. Premised on the assumption that capitalism can be overthrown primarily through the insurrectionary moment and/or a subsequent civil war, the theory belongs to social circumstances in which the fact of the modern military is unknown. Not only are modern armies and police trained to put down popular rebellions, the majority of people involved in a large-scale rebellion do 
not possess, as a whole, the same training and equipment. Liebknecht himself, thirteen years after writing Militarism, would experience the failure of the insurrectionary strategy when the Spartacist Rebellion was swiftly crushed--the state does not abhor, as the Invisible Committee assumes, a bloodbath. Since that time, through the experience of innumerable wars, the capitalist and imperialist war machine has become an apparatus capable of pacifying rebellious populations of untrained and poorly armed insurrectionists (as Derbent's list of failed insurrections above attests) or even prevent them from happening altogether. At best, to hope that an insurrection will complete its aims in the face of this reality is wishful thinking; at worst, if the possibility of a massacre is immanent, it is irresponsible.

Moreover, the military's ideological training is such that the majority of the armed forces, soldiers and police, are socialized into accepting their role as guardians of imperialism and capitalism who most probably will not be 'defeated politically.' While we should recognize the existence of war-resisting dissidents and disaffected veterans, to assume that a large population of soldiers and police will, in the moment of insurrection, add their experience and weapons to the revolution is a leap of faith. It is perhaps this strange faith in the revolutionary potential of sections of the military that caused some activists and anti-capitalist organizations to declare that the military intervention in the Egyptian uprisings was a good thing--at least one organization initially claimed that to call this intervention a "coup" was "lying propaganda" because it was part of the broader Egyptian Revolution. (Woods 2013) We now know the result of the military's intervention in that potential insurrection: a state of emergency, a crackdown on radicals, and a return to power of the class that had been temporarily overthrown.

\section{4}

Despite the fact that the theory of insurrection has achieved a level of normativity amongst anti-capitalist scholars and organizers at the centres of capitalism, it is not the only strategic theory. After the Russian Revolution there was the Chinese Revolution: whereas the former produced the strategy of insurrection, the latter produced the strategy of protracted people's war (PPW). Although we might argue that the Chinese Revolution was ultimately a failure, this should not prevent us from examining the veracity of its theory of strategy. As noted in the previous section, one does not have to be a Leninist to accept the theory of insurrection; similarly, one does not have to be a Maoist to take the theory of PPW seriously.

If there was indeed a process between 1905 and 1917, obscured by the assumption that the strategy of making revolution begins with 1917, then a theory of strategy that takes this guerrilla process into account may in fact be a theory that possesses universal application. PPW is one such theory of strategic process, though its potential universality is confused by its particular application in China. Here, then, is an intriguing proposition: 
could the strategic line codified after the Russian Revolution be a particularity misunderstood as a universality whereas, inversely, the strategic line theorized after the Chinese Revolution was a universality misunderstood as a particularity? More precisely, could it be that the revolution in Russia was actually the result of a vague protracted revolutionary process culminating in the insurrection of $1917 ?^{5}$ Although we should not make the mistake of defining the October Revolution as an example of PPW, and thus claim that Lenin did not conceptualize strategy according to the theory of insurrection, these questions are salient in light of Liebknecht's claim about the events of 1905 and could help us think through a strategy capable of undermining capitalist militarism. Furthermore, although PPW has been proposed as a universal theory of revolutionary strategy, it may also be the case that revolutionary strategy lacks universality. By examining PPW in this concluding section, then, I am more interested in demonstrating how it may tell us something about universal aspects of strategic theory that the theory of insurrection cannot answer rather than proving the universality of this counter-theory. ${ }^{6}$

The reason we should take the strategy of PPW seriously is because there have been various examples of its implementation, in the past few decades, that have demonstrated a larger level of success than insurrection. The people's war in Peru nearly overthrew state power but was eventually undermined by the arrest of the Communist Party of Peru's (PCP) leadership. The people's war in Nepal led to UN intervention that enshrined the party initially leading this revolution. The current people's war in India has produced a state of emergency. Whether or not we agree with the ideology of the organizations leading these revolutions is beside the point; the rejection of the Bolsheviks' ideology has not prevented anti-Leninists from accepting the theory of insurrection as normative. What matters, here, is whether or not the strategy in itself is more successful and applicable than insurrection. We may indeed argue that the PCP was an over-militarized organization guilty of grave errors; we may point out that the Maoists in Nepal betrayed their own revolution; we may argue that the Naxal revolutionaries in India offer nothing significant to the Indian people... But in this paper I am interested in whether or not the strategic line gleaned from these contemporary revolutions can teach us more about how to make revolution than the theory of insurrection. As noted earlier, the question of organization is a theoretical problem that is distinct from, though connected to, strategy. If we can separate these problems when it comes to the theory of insurrection--as we have--then we can do the same with the theory of PPW.

Beyond moralistic and political assessments of the aforementioned instances of

\footnotetext{
${ }^{5}$ As T. Derbent indicates, the New Communist Party of Italy (nPCI) argues that this is the case.

${ }^{6}$ Canada's Revolutionary Communist Party (PCR-RCP) is one organization, following the organizations associated with the now defunct Revolutionary International Movement (RIM) that argues for the universal applicability of PPW. A good summation of their argument, which I will not replicate here, can be found in their article More on the Question of Waging Revolutionary War in the Imperialist Countries (http://www.pcr-rcp.ca/en/archives/1164).
} 
PPW, however, is the long-standing assumption that this strategic theory applies only to the global peripheries that produces a theoretical scission: PPW is a strategy of making revolution in the peripheries, whereas insurrection applies to the modern, militarized capitalist states. Such an argument claims that the former strategy does not apply to the centres of capitalism since it concerns peasant armies that will surround the cities from the countryside--the failure of the insurrectionary theory is thus left unquestioned because its alternative has been dismissed as a strategy of peasant guerilla warfare. Indeed, the theory of PPW is often defined as applicable only to contexts where there is the possibility of popular, peasant armies and the ability to build red bases in economically underdeveloped regions. I want to suggest, however, that this articulation of PPW confuses the specific application of the strategy with its general theorization. My aim in the paragraphs below is not to provide a thorough articulation of the general theory of PPW, or prove its universal applicability, only to provide the broad brushstrokes of an alternative to the theory of insurrection that, at the very least, might teach us something about the fact of modern militarization.

According to Mao Zedong, the military aspect of PPW breaks down to three overlapping but distinct stages: “[ $t$ ] he first stage is one of the enemy's strategic offensive and our strategic defensive. The second stage is one of the enemy's strategic defensive and our preparation for counter-offensive. The third stage is one of our strategic counter-offensive and the enemy's strategic retreat." (Mao 1967, 136-137) Since Mao first theorized this strategy, these three stages have been simplified as: i) strategic defensive; ii) strategic equilibrium; iii) strategic offensive. (Derbent 2013, 19) The first stage is when the people's war is launched and, due to the power of the state, it must engage in creative guerrilla deployment; the second stage is when the revolutionary movement has achieved dual power; the third stage is when the revolutionary movement is in a position of strength to take state power. There are often shifts back and forth between these stages, based on the composition of forces, and a people's war never develops in a straight line. The reality of a revolutionary war, and the fact that the state controls a military that is trained in pacifying entire populations, means that it might be the case that a revolution will temporarily gain strategic equilibrium only to be thrust back into strategic defensive, or just begin strategic offensive only to retreat into preparation. Mao referred to this characteristic of people's war as a “'jigsaw” pattern.”(Mao 1967, 145)

Moreover, these stages should not be treated as purely military because they are intended to also function, together and as we shall see before, as an expression of politics through war. In this sense war takes on both a military and non-military dimension. Similarly to how capitalist functions to pacify its subjects in every aspect of life, PPW is intended to produce an unpacification by confronting capitalism in every area of life. In some ways this intersects with Stephen D'arcy's concept, mentioned earlier, of "strategies of attrition" but connects the protracted process of tradition with politicization and a "strategy of overthrow"--the latter of which D'arcy believes to be outdated due to his conflation with 
"overthrow" and the Leninist style of organization. (D'arcy 2009, 66) PPW theorists have typically conceptualized D'arcy's notion of "attrition" as the accumulation of forces that only makes sense when directed at the strategic end of capitalism.

In every context where a revolutionary movement has initiated a people's war, the state has always been far more powerful than the revolutionaries. Hence the "protracted" nature of the strategy that begins in "strategic defensive" where those launching such a war use guerrilla tactics, accumulating weapons and forces based on the tactics they employ, growing and consolidating slowly. Due to the fact of modern militarization, and the ability of this military to keep its populations divided and pacified, one cannot hope that a protracted legal struggle, without the experience and training that comes through a protracted military struggle, will lead to an armed insurrection capable of toppling better armed and better trained state forces in a frontal confrontation. The "jig-saw" nature of this strategic theory allows for a creative deployment, training, experience, and accumulation so that, if those moments of open clashes (which may in fact include insurrections) are ever defeated, there is still a possibility of retreat and resumption of the people's war rather than a thorough defeat. One only needs to look at the decades long people's war in the Philippines to recognize that this is the case: despite having suffered serious setbacks, where the US and its allies have intervened on the side of the state, the Communist Party of the Philippines and its New People's Army have continued to survive and retain "red bases" and "liberated zones" throughout the nation.

The concept of "red bases" and "liberated zones", where a people's army can move freely and establish the seeds of a counter-authority to the state, also needs to be separated from the particular nature of people's wars in peripheral contexts. Rather than treat these base areas as liberated zones in an underdeveloped countryside, the point is to think of areas of operation that can exist within the cracks of society amongst people who are won over to the movement's line so that the latter may establish its counter-hegemony. At the height of the "Troubles" in Belfast, for example, there were entire neighbourhoods that were under community rule; the police and the military, despite the militarization of the modern state, would not enter unless it was absolutely necessary. Although such no-go zones are not necessarily revolutionary, their existence proves that revolutionary base areas are possible for the same reason these no-go areas were possible.

What is more important than the military aspect of this theory, as discussed above, is its political aspect. Preceding the people's war and during the people's war, the revolution must also succeed in "accumulating forces" so as to embed itself in the masses and saturate society as a whole. Here is where this strategy is not just an explanation of guerrilla tactics but a strategy of mass mobilization: "[t]he mobilization of the common people throughout the country will create a vast sea in which to drown the enemy, create the conditions that will make up for our inferiority in arms and other things, and create the prerequisites for overcoming every difficulty in the war.” (Ibid., 154) Such a mobilization is a political mobilization where people are pulled into the orbit of the revolutionary movement because 
this movement is also involved, and has been involved before launching its war, in politicizing people. The revolutionary army becomes the people itself, because the people will want the movement to succeed, and the state will thus be unable to immediately recognize the fronts and bases of the movement.

To accumulate conscious and politicized forces is to slowly expand a sphere of counter-hegemony where the revolution that seeks to become hegemonic attempts, through a protracted process, to define itself as a legitimate alternate authority--to win the consent of the people. We can analyze the strategy of PPW according to Gramsci's concept of "war of position" where "the superstructures of civil society are like the trench-systems of modern warfare." (Gramsci 1971, 235) As discussed, the modern, capitalist state already understands that pacification must also be accomplished through a "war of position"--an ideological and cultural battle to maintain hegemony--as well as its cruder and more visceral methods of coercion. The strategy of people's war, due to its protracted nature, is also a strategy that, intended to be deployed in every terrain and level of a given society, has the same understanding of warfare. ${ }^{7}$ I am not arguing, here, that Gramsci was a theorist of PPW, or even anticipates PPW, only that this strategic approach takes his conception of hegemony into account.

In a qualified sense, we can also think of the strategy of PPW according to Deleuze and Guattari's concept of the rhizome that "may be broken, shattered at a given spot, but it will start up again on one of its old lines, or on new lines." (Deleuze and Guattari 1998, 9) Although there are significant limitations in using this concept, the comparison it permits between different forms of warfare is clear in the following analogy of chess and Go, an older strategy boardgame:

Chess is indeed a war, but an institutionalized, regulated, coded war, with a front, a rear, battles. But what is proper to Go is a war without battle lines, with neither confrontation nor retreat, without battles even: pure strategy, whereas chess is semiology. Finally, the space is not at all the same: in chess, it is a question of arranging a closed space for oneself, thus of going from one point to another, of occupying the maximum number of squares with the minimum number of pieces. In Go, it is a question of arraying oneself in an open space, of holding space, of maintaining the possibility of springing up at any point: the movement is not from one point to another, but becomes perpetual. (Ibid., 353)

This analogy is useful in explaining the differences between insurrection and PPW.

\footnotetext{
${ }^{7}$ The nPCI, it is worth noting, has explicitly linked Gramsci's concept of "war of position" with the strategy of PPW in a document entitled Gramsci and the Protracted Revolutionary People's War (http://www.nuovopci.it/eile/en/gramsci_prpw.html).
} 
Whereas the former is defined by a coded and linear system where the state is eventually confronted as a front, the latter is defined by moving across the entire social space with a "minimum number of forces" so as to slowly accumulate and consolidate at every point in multiple chains of resistance. Although this appeal to the concept of the rhizome is not entirely perfect, the analogy of chess and Go might be metaphorically useful in explaining the significant difference between the two theories of strategy.

The overall point is that the theory of PPW possesses less rigidity than the theory of insurrection: it is not about gambling everything on a single uprising, hoping that the state will disarm itself in the face of the defiant masses, but about a tortured process of slowly building and training a mass movement in the cracks that exist in all societies, no matter how militarized, and continuing to accumulate forces and saturate every social space and structure. The crushing of an insurrection crushes the movement itself since the insurrection is the moment upon which the movement as a whole gambles. As aforementioned, we only need to look at the failed insurrections post-1917 to recognize that this has been the case. On the other hand, it is difficult to crush a strategic deployment of revolutionary forces that spreads throughout the entire social terrain; a people's war cannot easily be beheaded due to its immanence. The beheading of such a movement will come from elsewhere, such as the defeat of the people's war in Peru due to the capture of its leadership and the movement's inability to deal with the contradictions produced by this leadership's supposed denunciation of the war. ${ }^{8}$

We should know from experience that urban guerrilla movements at the centres of capitalism, despite their obvious historical problems, have caused more problems for capitalism than those failed or imagined insurrections. The Red Army Faction, for example, persisted until the late 1990s when it voluntarily chose to disband, despite all attempts of the German state to exterminate its members. The failure of these guerrilla movements was not in their guerrilla tactics but in their strategic line: they failed to accomplish any revolutionary aims because the telos of their ideology was still insurrection--the Guevera-influenced focoism they expressed was intended to spark "an insurrectionary general strike." (Derbent $2013,21)$ The fact that guerrilla movements can survive at the centres of capitalism should tell us something about the inability of the state to easily weed out and crush urban guerrilla tactics. (Conversely, in the frontal confrontation necessitated by a general insurrection, where the state is presented directly with an armed population that has not developed into a fighting force through a protracted process, the capitalist military's ability to crush a potential revolution is easier.) If PPW advocates a process of embedding potential guerrilla movements across broad populations, and thus gaining popular sympathy, then it is more promising than these disconnected guerrilla experiences that still survived for decades

\footnotetext{
${ }^{8}$ For more information, see the various articles about this period in the Peruvian people's war in the 1996 issue of A World To Win (http://www.aworldtowin.org/back_issues/1996-22/index.htm).
} 
despite being unable to produce a larger revolutionary movement. ${ }^{9}$

In November 2000 Action Socialiste, a now defunct socialist organization from Quebec, wrote:

The fact is that 150 years of [Marxist theory]... should have been oriented in an almost singular direction: solving the question of the proletarian revolution. Especially since, in 1848, Marx and Engels concluded their founding manifesto by openly admitting this very fact: "[communists] openly declare that their ends can be attained only by the forcible overthrow of all existing social conditions." Thus, the question of proletarian revolution is not a purely decorative aspect, nor a subsidiary question that we leave to randomness and improvisation. (Action Socialiste 2000) ${ }^{10}$

Since the Manifesto was written, capitalist militarization has developed into a powerful system of pacification that is able to enforce ruling class power in a manner anticipated by Liebknecht in 1906. The question raised, first by Engels and then by Liebknecht, regarding the necessity of revolutionary strategy capable of responding to this militarism still needs to be answered. Indeed, the questions of strategic theory should be intrinsic to any socialist project interested in transgressing the limits of capitalism; they cannot be substituted by those related questions of organization and tactics. Although the theory of protracted people's war might provide us with a clue of how we might respond to this necessity, we cannot adopt it merely as a formula to be applied unthinkingly in every context. After all, the theory of insurrection has become the normative conceptualization of revolutionary strategy--often unquestioned or reified--due to a similar uncritical mindset that would have us ignore the problematic of revolutionary strategy by pretending that it is already solved. We need to begin thinking through this problematic now, alongside the problematic of organization, so that it does not remain under-theorized by the time it is too late.

\section{References Cited}

Action Socialiste, "The Communist Party Must Lead the War the Revolutionary War in the Imperialist Centres." In Socialisme Maintenant! 5 (2000). (English translation is available online: http://www.pcr-rcp.ca/en/archives/1248).

\footnotetext{
${ }^{9}$ For more information on the survival of these movements that were successful in their partial resemblance to the strategy of PPW, the multi-volume The Red Army Faction: A Documentary History (J. Smith and Andre Moncourt) and Strike One to Educate One Hundred: the Rise of the Red Brigades in Italy (Chris Aronson Beck, Reggie Emilia, Lee Morris, and Ollie Patterson) are particularly illuminating.

${ }^{10}$ The awkwardness of this quotation is due to its translation from the French.
} 
D'arcy, Stephen. "Strategy, Meta-strategy and Anti-capitalist Activism." In The Journal for the Society of Socialist Studies 5 (2009), 64-89.

Dean, Jodi. The Communist Horizon. London: Verso, 2012.

Deleuze, Gilles and Felix Guattari. A Thousand Plateaus. Minneapolis: University of Minnesota Press, 1998.

Derbent, T. Categories of Military Policy. Montreal: Kersplebedeb, 2013.

Egan, Daniel. "Rethinking War of Maneuver / War of Position: Gramsci and the Military Metaphor." Critical Sociology 40 (2014), 521-538.

Engels, Friedrich. "Conditions and Prospects of a War of the Holy Alliance Against France in 1852." Karl Marx and Friedrich Engels: Collected Works 10 (London: Lawrence \& Wishart, 1978), 542-566.

Gramsci, Antonio. Selections from the Prison Notebooks. New York: International Publishers, 1971.

Invisible Committee, The. The Coming Insurrection. Los Angeles: Semiotext(e), 2009.

Liebknecht, Karl. Militarism. Toronto: William Briggs, 1917.

Mao Zedong. "On Protracted War." The Selected Works of Mao Zedong 2 (Peking: Foreign Languages Press, 1967), 113-194.

Neocleous, Mark, George Rigakos and Tyler Wall. "On Pacification: Introduction to the Special Issue." The Journal for the Society of Socialist Studies 9 (2013), 1-6.

Neuberg, A. Armed Insurrection. New York: New Left Books, 1970.

Panitch, Leo, Gregory Albo and Vivek Chibber (eds.). Socialist Register 49 (2013).

Woods, Alan. “The Second Egyptian Revolution.” In Defense of Marxism (http://www.marxist.com/second-egyptian-revolution.htm), 2013. 